\title{
PENGARUH LINGKUNGAN KERJA DAN DISIPLIN KERJA TERHADAP KINERJA KARYAWAN CV. CAHAYA LESTARI PALEMBANG"
}

\author{
Dra. Hj. Delimawati, M.Si \\ Dosen Fakultas Ekonomi Universitas Palembang
}

Tujuan dalam penelitian ini adalah untuk mengetahui pengaruh pelatihan dan kompetensi terhadap kinerja karyawan CV. Cahaya Lesatari Palembang. Metode penelitian yang dilakukan adalah penelitian asosiatif kausal dimana variabel diukur dengan skala likert. Metode pengumulan dilakukan dengan daftar pertanyaan (kuesioner) dan wawancara. Populasi dalam penelitian ini adalah seluruh karyawan CV. Cahaya Lestari Palembang yang berjumlah 34 orang karyawan, penarikan sampel dengan metode sampling jenuh. Pengelahan data menggunakan aplikasi SPSS Ver 24,00 dengan analisis deskriptif dan pengujian hipotesis dengan analisis regresi berganda.

Hasil penelitian menunjukan bahwa : (1). Secara parsial variabel lingkungan kerja mempengaruhi kinerja karyawan $\mathrm{CV}$. Cahaya Lesatari Palembang dengan nilai t-hitung sebesar $(4,494)$ sedangkan nilai t tabel $(2,007)$, pada variabel komptensi mempengaruhi kinerja karyawan CV. Sapayona Palembang dengan nilai t-hitung sebesar $(5,403)$ sedangkan nilai t tabel $(2,007)$. (2) Secara simultan variabel pelatihan dan kompetensi mempengaruhi kinerja karyawan CV. Sapayona Palembang dengan nilai F-hitung sebesar $(12,091)$ sedangkan nilai t tabel $(3,291)$.

\section{Kata Kunci : Pelatihan. Kompetensi \& Kinerja}

\section{PENDAHULUAN}

\subsection{Latar Belakang}

Sumber daya manusia merupakan salah satu aset penting penting didalam menjalankan sebuah organisasi. Sumber daya manusia secara tidak langsung mempengaruhi efisiensi dan efektifitas perusahaan. Dalam hal tersebut perusahaan sadar bahwa karyawan merupakan investasi yang sangat bernilai. Manajemen sumber daya manusia merupakan bagian dari manajemen keorganisasian yang memfokuskan diri pada unsur sumber daya manusia. Tugas manajemen sumber daya manusia adalah mengelola sumber daya manusia secara baik agar diperoleh tenaga kerja yang puas akan pekerjaannya.

Saat ini mencari dan mengumpulkan tenaga kerja yang berkinerja baik sangalah tidak mudah, terlebih dalam mempertahankan yang sudah ada. Oleh karena itu perusahaan harus memprioritaskan karyawan yang berkeahlian dan memiliki kinerja yang baik agar dapat dilatih, dimotivasi, dan dikembangkan sesuai yang dikehendaki perusahaan dalam mempertahankan karyawan yang berkualitas. Salah satu alat ukur untuk menentukan efektifitas perusahaan adalah hasil kinerja karyawan. Kinerja karyawan sangat diharapkan oleh perusahaan dalam rangka merealisasikan tujuan oleh perusahaan baik tujuan jangka panjang maupun tujuan jangka pendek. Mathis (2016: 78) berpendapat bahwa kinerja karyawan adalah apa yang dilakukan atau tidak oleh karyawan mempengaruhi seberapa banyak mereka memberi kontribusi kepada organisasi. Menurut Mangkunegara (2004: 67) Pengertian kinerja adalah hasil kerja secara kualitas dan kuantitas yang dicapai seorang pegawai dalam melaksanakan tugas 
sesusai dengan tanggung jawab yang diberikan.

Pencapaian tujuan berbasis manajemen sumber daya manusia akan menunjukkan bagaimana seharusnya perusahaan dalam mendapatkan, mengembangkan, membina, mengevaluasi, serta mensejahterakan karyawan dalam jumlah (kuantitas) dan tipe (kualitas) yang tepat. Manajemen sumber daya manusia merupakan "pengakuan" akan pentingnya sumber daya manusia dalam pencapaian tujuan organisasi, pemanfaatan berbagai fungsi dan kegiatan karyawan guna menjamin bahwa mereka dibina secara efektif dan bijak agar bermanfaat bagi individu, organisasi, bahkan masyarakat secara luas (Handoko, 2015: 15).

CV. Cahaya Lestari Palembang adalah perusahaan swasta yang bergerak dibidang general kontraktor, maintenance dan supplier. Adapun etos kerja yang diterapkan oleh CV. Cahaya Lestari Palembang ternyata belum dapat meningkatkan antusianisme karyawan untuk bekerja.

Berdasarkan hasil pengamatan dan wawancara dengan Bapak Deddy Suharyadi, ST. pemilik CV. Cahaya Lestari Palembang pada tanggal 20 Desember 2020 diketahui bahwa kerjasama antar sesama rekan kerja di perusahaan masih belum maksimal, terlihat dari masih adanya karyawan yang lebih suka bekerja secara individu daripada harus bekerja bersama. Padahal kerjasama dalam tim kerja harusnya menjadi sebuah kebutuhan dalam mewujudkan keberhasilan kinerja dan kinerja. Selain itu di kasus lain, keterlambatan dalam penyelesaian pengerjaan suatu proyek juga kerap kali terjadi yang mengakibatkan penumpukan pekerjaan yang harus diselesaikan. Hal ini mengindikasikan bahwa kerjasama antar sesama rekan kerja masih belum maksimal sebagaimana yang diharapkan.

Faktor lain yang mempengaruhi menurunnya kinerja karyawan pada $\mathrm{CV}$. Cahaya Lestari Palembang adalah lingkungan kerja dan disiplin kerja kerja. Menurut Alex S. Nitisemito (2015:67) berpendapat bahwa indikator dari lingkungan kerja adalah suasana kerja, hubungan dengan rekan kerja, hubungan antara bawahan dengan pimpinan, tersedianya fasilitas untuk karyawan. Kondisi fisik perusahaan yang belum tertata rapih serta ruang kerja yang masih belum kondusif dinilai sebagai faktor penghambat dalam meningkatkan kinerja karyawan. Tempat kerja masih dalam proses renovasi sehingga karyawan sering kali terganggu dengan suasana yang kurang nyaman, dan ukuran ruangan yang kurang luas mengakibatkan tumpukan peralatan kerja ada di manamana.

Selanjutnya dikatakan oleh Bapak Deddy Suharyadi, ST. bahwa disiplin kerja karyawan CV. Cahaya Lestari Palembang masih dapat katakan rendah, hal ini merupakan faktor yang perlu mendapatkan perhatian dari pimpinan. Menurut Veithzal Rivai (2015:67) mengemukakan bahwa indikator yang digunakan untuk mengukur disiplin kerja adalah kehadiran, ketaatan pada peraturan kerja, ketaatan pada standar kerja, tingkat kewaspadaan tinggi, dan bekerja etis. Hal ini dapat dilihat dari daftar absensi karyawan

Tabel. 1

Rekapitulasi Absensi Karyawan

CV. Cahaya Lestari Palembang

Tahun 2016 - 2020

\begin{tabular}{|c|c|c|c|c|c|}
\hline Keterangan & 2016 & 2017 & 2018 & 2019 & 2020 \\
\hline Sakit dengan keterangan & & & & & \\
\hline
\end{tabular}




\begin{tabular}{|l|c|c|c|c|c|}
\hline 1-2 hari & 8 & 8 & 10 & 6 & 11 \\
\hline 3-4 hari & 5 & 5 & 6 & 4 & 6 \\
\hline$>5$ hari & - & 1 & 1 & 2 & - \\
\hline Sakit tanpa keterangan & & & & & \\
\hline 1-2 hari & 4 & 4 & 5 & 3 & 6 \\
\hline 3-4 hari & 2 & 3 & 3 & 4 & 5 \\
\hline$>5$ hari & - & - & - & & \\
\hline Izin & & & & & \\
\hline 1-2 hari & 6 & 6 & 7 & 5 & 6 \\
\hline 3-4 hari & 1 & 3 & 3 & 4 & 4 \\
\hline$>5$ hari & - & 1 & 2 & - & 3 \\
\hline Tanpa keterangan & & & & & \\
\hline 1-2 hari & 2 & 3 & 4 & 3 & 3 \\
\hline 3-4 hari & 2 & 3 & 3 & 3 & 4 \\
\hline$>5$ hari & - & - & - & - & - \\
\hline Terlambat & 4 & 6 & 5 & 6 & 6 \\
\hline & & & & & \\
\hline
\end{tabular}

CV. Cahaya Lestari Palembang (2020)

Dari tebel 2 di atas dapat dilihat bahwa kedisiplinan CV. Cahaya Lestari Palembang mengalami penurunan, dimana masalah kedisiplinan berkaitan dengan kinerja. Pada tahun 2016 sakit dengan keterangan ada 13 orang, sakit tanpa keterangan 6 orang, izin ada 7 orang, tanpa keterangan ada 4 orang dan terlambat 4 orang. Pada tahun 2017 sakit dengan keterangan ada 14 orang, sakit tanpa keterangan 7 orang, izin ada 10 orang, tanpa keterangan ada 6 orang dan terlambat 6 orang. Pada tahun 2018 sakit dengan keterangan ada 17 orang, sakit tanpa keterangan 8 orang, izin ada 12 orang, tanpa keterangan ada 7 orang dan terlambat 5 orang. Pada tahun 2019 sakit dengan keterangan ada 12 orang, sakit tanpa keterangan 7 orang, izin ada 9 orang, tanpa keterangan ada 6 orang dan terlambat 6 orang. Pada tahun 2020 sakit dengan keterangan ada 17 orang, sakit tanpa keterangan 11 orang, izin ada 13 orang, tanpa keterangan ada 7 orang dan terlambat 6 orang

Lebih lanjut dikatakan oleh Bapak Deddy Suharyadi, ST, agar para karyawan disiplin, pimpinan perusahaan telah memberikan pemotongan gaji dan insentif serta surat peringatan. Sejauh ini tercatat sudah 5 orang karyawan yang mendapatkan surat peringatan (SP), 2 orang mendapat SP 1, 4 orang mendapat SP 2, dan 2 orang mendapat SP 3 . Pemberian surat peringatan ini antara lain atas dasar keterlambatan hadir di kantor, ketidak hadiran tanpa keterangan, serta kelalaian dalam bekerja.

Berdasarkan fenomena yang terjadi diatas maka penulis tertarik untuk mengadakan penelitian dengan judul "Pengaruh Lingkungan Kerja dan Disiplin Kerja Terhadap Kinerja Karyawan CV. Cahaya Lestari Palembang"

\subsection{Perumusan Masalah}

Berdasarkan latar belakang diatas maka dapat ditarik perumusan masalah sebagai berikut :

1. Apakah lingkungan kerja dan disiplin kerja berpengaruh secara parsial terhadap kinerja karyawan $\mathrm{CV}$. Cahaya Lestari Palembang ?

2. Apakah lingkungan kerja dan disiplin kerja berpengaruh secara simultan terhadap kinerja karyawan $\mathrm{CV}$. Cahaya Lestari Palembang? 


\section{TINJAUAN PUSTAKA}

A. Lingkungan Kerja

1. Pengertian Lingkungan Kerja

Penciptaan lingkungan kerja

yang menyenangkan dan dapat memenuhi kebutuhan karyawan akan memberikan rasa puas dan mendorong semangat kerja mereka. Menurut Logahan (2015: 14) lingkungan kerja adalah segala sesuatu yang ada di sekitar karyawan yang dapat mempengaruhi dirinya dalam menjalankan tugas-tugas yang sudah diembankan padanya. Lingkungan kerja yang kurang mendapat perhatian akan membawa dampak negatif dan menurunkan semangat kerja, hal ini disebabkan karyawan. dalam melaksanakan tugas mengalami gangguan, sehingga kurang semangat dan kurang mencurahkan tenaga dan pikirannya terhadap tugasnya. Dengan lingkungan kerja yang baik dan nyaman, para karyawan akan dapat bekerja dengan baik tanpa adanya gangguan yang berarti, misalnya polusi asap, polusi udara dan gangguan yang lainnya. Oleh karena itu lingkungan kerja yang baik sangat diperlukan oleh setiap orang pada saat bekerja.

\section{Faktor yang Memengaruhi Lingkungan Kerja}

Menurut Sedarmayanti ( 2016:102 ) menyatakan bahwa secara garis besar, jenis lingkungan kerja terbagi menjadi 2 yaitu:

a. Lingkungan Kerja Fisik

1. Pewarnaan

2. Penerangan

3. Udara

4. Suara bising

5. Ruang Gerak

6. Keamanan

7. Kebersihan

2. Lingkungan Kerja Non Fisik

1. Struktur kerja,

2. Tanggung jawab kerja,
3. Perhatian dan dukungan pemimpin,

4. Kerja sama antar kelompok,

5. Kelancaran komunikasi,

Sedangkan menurut Alex S. Nitisemito (2015:82) yang dapat memengaruhi terbentuknya suatu kondisi lingkungan kerja dikaitkan dengan kemampuan karyawan, diantaranya:

1) Warna

2) Kebersihan lingkungan kerja

3) Penerangan

4) Pertukaran udara

5) Jaminan terhadap keamanan menimbulkan ketenangan.

6) Kebisingan

7) Tata ruang

\section{B. Disiplin Kerja}

\section{Pengertian Disiplin Kerja}

Menurut Ahmad

Tohardi (2016:46) disiplin kerja merupakan perilaku seseorang yang sesuai dengan peraturan prosedur kerja yang ada. Disiplin kerja adalah suatu alat yang digunakan para manajer untuk berkomunikasi dengan karyawan agar mereka bersedia untuk mengubah suatu perilaku serta sebagai suatu upaya untuk meningkatkan kesadaran dan kesediaan seseorang menaati semua peraturan perusahaan dan norma-norma sosial yang berlaku (Rivai, 2015:56). Menurut Hasibuan (2015:45) berpendapat bahwa kedisiplinan adalah kesadaran dan kesediaan seseorang menaati semua peraturan perusahaan dan norma-norma sosial yang berlaku.

\section{Indikator Disiplin Kerja}

Menurut Veithzal Rivai (2015:56), disiplin kerja memilki lima indikator sebagai berikut:

1) Kehadiran. Hal ini menjadi indikator yang mendasar untuk mengukur kedisiplinan, dan biasanya karyawan yang memiliki disiplin 
kerja rendah terbiasa untuk terlambat dalam bekerja.

2) Ketaatan pada peraturan kerja. Karyawan yang taat pada peraturan kerja tidak akan melalaikan prosedur kerja dan akan selalu mengikuti pedoman kerja yang ditetapkan perusahaan.

3) Ketaatan pada standar kerja. Hal ini dapat dilihat dari besarnya tanggungjawab karyawan terhadap tugas yang diamanahkan kepadanya.

4) Tingkat kewaspadaan tinggi. Karyawan memiliki kewaspadaan tinggi akan selalu berhati-hati, penuh perhitungan dan ketelitian dalam bekerja, serta selalu menggunakan sesuatu secara efektif dan efisien.

5) Bekerja etis. Beberapa karyawan mungkin melakukan tindakan yang tidak sopan ke pelanggan atau tqerlibat dalam tindakan yang tidak pantas. Hal ini merupakan salah satu bentuk tindakan indisipliner, sehingga bekerja etis sebagai salah satu wujud dari disiplin kerja karyawan.

Sedangkan menurut Soejono (2014:11), indikator dari disiplin kerja yaitu :

a Ketepatan waktu,

Para karyawan datang ke tempat kerja tepat waktu, tertib dan teratur, dengan begitu dapat dikatakan disiplin kerja baik.

b Menggunakan peralatan dan perlengkapan dengan baik,

Sikap hati-hati dalam menggunakan peralatan dan perlengkapan, dapat menunjukkan bahwa seseorang memiliki disiplin kerja yang baik, sehingga peralatan dan perlengkapan dapat terhindar dari kerusakan.

c Tanggung jawab yang tinggi,

Karyawan senantiasa menyelesaikan tugas yang dibebankan kepadanya sesuai dengan prosedur dan bertanggung jawab atas hasil kerja, dapat pula dikatakan memiliki disiplin kerja yang baik.

d Ketaatan terhadap aturan tempat bekerja.

e Karyawan memakai seragam, Menggunakan kartu tanda pengenal identitas, membuat izin bila tidak masuk kerja, juga merupakan cerminan dari disiplin yang tinggi.

\section{Kinerja}

\section{Pengertian Kinerja}

Kinerja sangat diharapkan oleh perusahaan dalam merealisasikan tujuan-tujuan perusahaan, balk jangka pendek maupun jangka panjang. Prestasi keria yang diraih oleh karyawan tidak terlepas dan adanya manajemen dalam menciptakan kinerja itu sendiri. Kinerja adalah hasil upaya seseorang yang ditentukan oleh kemampuan karakteristik pribadinya serta persepsi terhadap perannya terhadap pekerjaan itu (Sutrisno, 2017:149). Menurut AA. Anwar Prabu Mangkunegara (2015:67) kinerja adalah hasil kerja secara kualitas dan kuantitas yang dicapai oleh seseorang pegawai dalam melaksanakan tugasnya sesuai dengan tanggung jawab yang diberikannya. Sedangkan menurut Malayu SP. Hasibuan (2015:94) kinerja adalah suatu hasil kerja yang dicapai seseorang dalam melaksanakan tugas yang dibebankan kepadanya didasarkan atas kecakapan, pengalaman, kesungguhan serta waktu.

\section{Faktor-faktor Yang Mempengaruhi Kinerja}

Dalam pencapain kinerja yang baik tentunya ada faktor-faktor yang mempengaruhinya.. Menurut AA. Anwar Prabu Mangkunegara (2015:67) menyatakan ada banyak faktor yang mempengaruhi kinerja karyawan :

1. Kualitas keria, 
2. Kuantitas kerja,

3. Tanggung jawab,

4. Inisiatif

5. Kerja sama,

6. Ketaatan

D. Kerangka Fikir
Menurut Heidrahman dan Suad Husnan $(2015$; 159) faktor-faktor kinerja yang perlu dinilai adalah sebagai berikut:

1. Kuantitas Kerja

2. Kualitas Kerja

3. Inisiatif

4. Sikap

Gambar 1

Kerangka Pikir

Lingkungan Kerja $\left(\mathrm{X}_{1}\right)$

1. Fisik
a. Pewarnaan
b. Penerangan
c. Udara
d. Kebisingan
e. Ruang Gerak
f. Keamanan
g. Kebersihan

2. Non FisiK
a. Struktur kerja
b. Tanggungjawab kerja
c. Perhatian dan dukumgan
d. Kerjasama antar kelompok
e. Kelancaran komunikasi
(Sedarmayanti 2015;102)

a. Kualitas kerja

b. Kuantitas kerja

c. Tanggungjawab

d. Inisiatif

e. Kerjasama

f.Ketaatan

Disiplin Kerja $\left(\mathrm{X}_{2}\right)$

a. Ketepatan waktu

b. Menggunakan peralatan dan perlengkapan dengan baik

c. Tanggung jawab yang tinggi

d. Ketaatan terhadap aturan tempat bekerja

e. Karyawan memakai seragam, 


\section{E. Hipotesis}

Ho: Tidak ada pengaruh lingkungan kerja dan disiplin kerja secara parsial terhadap kinerja karyawan pada CV. Cahaya Lestari Palembang.

$\mathrm{H}_{1}$ : Ada pengaruh lingkungan kerja dan disiplin kerja secara parsial terhadap kinerja karyawan pada CV. Cahaya Lestari Palembang.

Ho: Tidak ada pengaruh lingkungan kerja dan disiplin kerja secara simultan terhadap kinerja karyawan pada CV. Cahaya Lestari Palembang.

$\mathrm{H}_{1}$ : Ada pengaruh lingkungan kerja dan disiplin kerja secara simultan terhadap kinerja karyawan pada CV. Cahaya Lestari Palemban

\section{METODOLOGI PENELITIAN}

\subsection{Objek Penelitian}

Objek penelitian dilakukan di

CV. Cahaya Lestari Palembang yang berlokasi di Jalan Angkatan 66 No. 2013 Kemuning Palembang.

\subsection{Desain Penelitian}

Desain penelitian ini adalah penelitian asosiatif kausal dengan menggunakan pendekatan kuantitatif. Penelitian asosiatif kausal adalah penelitian yang bertujuan untuk mengetahui pengaruh antara dua variabel atau lebih (Umar, 2015:34). Penelitian ini menjelaskan hubungan memengaruhi dan dipengaruhi dari variable- variabel yang akan diteliti. Adapun pendekatan yang digunakan pada penelitian ini adalah pendekatan kuantitatif karena data yang akan digunakan untuk menganalisis hubungan antar variabel dinyatakan dengan angka atau skala numerik. Penelitian ini menganalisis pengaruh lingkungan kerja dan disiplin kerja terhadap kinerja karyawan

\subsection{Jenis Data dan Sumber Data}

a. Data primer

Data primer yaitu data yang diperoleh langsung melalui wawancara dengan pihak responden khususnya dengan menggunakan quesioner dan mengajukan sejumlah pertanyaan sesuai dengan indikator yang akan diteliti dan hal lain yang mendukung isi penelitian ini.

b. Data sekunder

Data Sekunder yaitu teknik pengumpulan data yang bersumber dari dokumen-dokumen yang berkaitan dengan permasalahan dan pembahasan dalam penelitian ini yang ada diperusahaan.

\subsection{Teknik Analisis}

\subsubsection{Analisis Deskriptif Data}

Analisis deskriptif adalah cara merumuskan dan menafsirkan data yang ada sehingga memberikan gambaran yang jelas mengenai data yang akan diteliti yaitu :

a. Deskriptif responden

Yang menggambarkan keadaan responden berdasarkan usia, jenis kelamin, dan jenjang pendidikan

b Deskriptif variabel penelitian

Memberikan gambaran mengenai variabel yang akan diteliti tentang lingkungan kerja, disiplin kerja serta pengaruhnya terhadap kinerja. Analisis deskriptif dilakukan peneliti yaitu dengan mendistribusikan jawaban responden dalam bentuk tabel sehingga memperoleh gambaran yang jelas tentang distribusi jawaban responden terhadap variabel penelitian.

\subsubsection{Uji Instrumen}

Untuk mengetahui data yang diperoleh dengan kuesioner dapat valid dan reliabel maka perlu dilakukan uji validitas dan reabilitas kuesioner terhadap butir- butir pertanyaan. Dari hasil uji validitas dan uji reliabilitas dapat diketahui layak tidaknya data yang 
terkumpulkan. Dengan menggunakan instrumen yang valid dan reliabel diharapkan hasil penelitian akan menjadi valid dan relaiabel (Sugiyono, 2015).

a. Uji Validitas

Uji validitas adalah uji yang dilakukan untuk memastikan kemampuan sebuah skala untuk mengukur konsep yang dimaksudkan. Dengan kata lain uji validitas digunakan untuk mengukur sah atau valid tidaknya suatu kuesioner. Suatu kuesioner dikatakan valid jika pertanyaan kuesioner mampu mengungkapkan sesuatu yang akan diukur oleh kuesioner tersebut (Ghozali, 2011). Validitas dalam penelitian menyatakan derajat ketepatan alat ukur penelitian terhadap isi atau arti sebenarnya yang diukur.

\section{b. Uji Reliabilitas}

Reliabilitas adalah alat untuk mengukur suatu kuesioner yang merupakan indikator dari variabel atau konstruk. Realibilitas menunjukkan konsistensi dan stabilitas dari suatu skor (skala pengukuran). Suatu kuesioner dikatakan reliabel atau handal jika jawaban seseorang terhadap pertanyaan adalah konsisten atau stabil dari waktu ke waktu (Ghozali, 2015:48). Instrumen yang reliabel adalah instrumen yang jika dicobakan secara berulang-ulang pada kelompok yang sama akan menghasilkan data yang sama dengan asumsi tidak terdapat perubahan psikologis terhadap responden. Dengan metode Alpha Cronbach, koefisien yang diukur akan beragam antara 0 hingga 1. Suatu konstruk atau variabel dikatakan reliabel jika memiliki nilai Alpha Cronbabch > 0,60 (Ghozali, 2015:52). Nilai alpha cronbach yang mendekati 1 menandakan reliabilitas dengan konsistensi tinggi

\subsubsection{Analisis Deskriptif Statistik}

a. Koefesien Diterminasi

Untuk mengetahui seberapa besar kemampuan variabel independen (X) menjelaskan variabel dependen (Y).
Semakin besar nilai koefisien determinasi, maka semakin baik kemampuan variabel bebas (X) menerangkan variabel terikat $(\mathrm{Y})$. Jika determinasi (r) semakin besar atau mendekati satu, maka dapat dikatakan bahwa variabel bebas (X) semakin kuat menjelaskan variabel terikat (Y). Koefisien determinasi (r) pada intinya mengukur seberapa jauh kemampuan model dalam menerangkan variasi variabel dependen. Nilai koefisien determinasi adalah antara nol dan satu. Nilai $r=$ yang kecil berarti kemampuan variabel independen (X) dalam menjelaskan variasi variabel dependen (Y) sangat lemah.

$$
\mathrm{r}=\frac{\left(\mathrm{n}\left(\sum X Y^{2}\right)-\left(\sum X Y\right)^{2}\right.}{\left(\mathrm{n}\left(\sum \mathrm{X}^{2}\right)-\left(\sum X\right)^{2}\left(\mathrm{n}\left(\sum Y 2\right)-\left(\sum Y\right)^{2}\right.\right.}
$$

\section{b. Uji Regresi}

Uji hipotesis bertujuan untuk mengetahui apakah terdapat pengaruh yang jelas dan dapat dipercaya antara variabel independen (lingkungan kerja dan disiplin kerja) terhadap variabel dependen (kinerja karyawan). Pengujian hipotesis menggunakan uji regresi berganda. Dalam analisis regresi, dikembangkan sebuah persamaan regresi yaitu suatu formula yang mencari nilai variabel dependen dari nilai variabel independen yang diketahui. Analisis regresi digunakan untuk tujuan peramalan, dimana dalam model tersebut ada satu variabel dependen dan dua atau lebih variabel independen.

Untuk mengetahui apakah variabel independen berpengaruh atau tidak terhadap variabel dependen maka dapat dilihat dari taraf signifikansinya dengan standar signifikansi 5\%. Apabila tingkat signifikansi yang diperoleh dari hasil lebih dari 5\% maka hipotesis ditolak, sebaliknya jika hasil uji hipotesis berada di antara 0-5\% maka hipotesis diterima. Sementara itu, untuk melihat regresi yang dihasilkan berpengaruh positif atau negatif melalui koefisien beta $(\beta)$. Apabila koefisien beta memiliki tanda minus (-) 
berarti pengaruh yang dihasilkan adalah negatif, sebaliknya apabila koefisien beta tidak memiliki tanda minus (-), maka pengaruh yang dihasilkan adalah positif (+) (Ghozali, 2016:43). Dalam penelitian ini analisis regresi berganda digunakan oleh peneliti, karena peneliti bermaksud meramalkan bagaimana keadaan (naik turunnya) variabel dependen (kriterium).

Persamaan regresi untuk dua prediktor adalah:

$$
\mathbf{Y}=\mathbf{a}+\mathbf{b}_{1} \mathbf{X}_{1}+\mathbf{b}_{2} \mathbf{X}_{2}+\mathbf{e}
$$

Dimana:

$$
\begin{aligned}
& \mathrm{Y}=\text { Kinerja } \\
& a \quad=\text { Konstanta } \\
& b_{1}, b_{2}=\text { Koefesien regresi } \\
& X_{1}=\text { Lingkungan kerja } \\
& X_{2}=\text { Disiplin kerja }
\end{aligned}
$$

\section{c. Uji Signifikansi}

- Uji f

Uji-f hitung dilakukan untuk melihat secara bersama-sama bagaimana pengaruh variabel lingkungan kerja $\left(\mathrm{X}_{1}\right)$ dan disiplin kerja $\left(\mathrm{X}_{2}\right)$ terhadap prestasi kerja (Y). Nilai f hitung dapat diperoleh dengan menggunakan bantuan aplikasi software SPSS 24.0 for Windows. Selanjutnya nilai $\mathrm{f}_{\text {hitung }}$ akan dibandingkan dengan nilai $\mathrm{f}$ Tabel dengan kriteria kesalahan $(\alpha=5 \%)$ dan derajat kebebasan $(\mathrm{df})=(\mathrm{n}-\mathrm{k}),(\mathrm{k}-2)$ atau dapat dirumuskan :

$$
\mathrm{f}_{\text {hitung }}=\frac{\mathrm{r}^{2} /(\mathrm{k}-1)}{1-\mathrm{r}^{2} / \mathrm{n}-\mathrm{k}}
$$

- Uji t

Uji - $\mathrm{t}$ hitung dua arah bertujuan untuk melihat secara parsial bagaimana pengaruh variabel lingkungan kerja $\left(\mathrm{X}_{1}\right)$ atau disiplin kerja $\left(\mathrm{X}_{2}\right)$ terhadap variabel kinerja (Y). Model hipotesis yang digunakan dalam uji t hitung dua arah ini adalah : Nilai $\mathrm{t}$ hitung dapat diperoleh dengan menggunakan bantuan aplikasi software SPSS 24,0 for Windows. Nilai t hitung selanjutnya akan dibandingkan dengan nilai $t$ tabel dengan tingkat kesalahan $(\alpha=5 \%)$ dan derajat kebebasan $(\mathrm{df})=(\mathrm{n}-\mathrm{k})$, atau dapat dirumuskan sebagai berikut :

$$
\mathbf{t}_{\text {hitung }}=\frac{\mathbf{r} \sqrt{ }(\mathbf{n}-2}{\sqrt{1-\mathbf{r}^{2}}}
$$

\section{HASIL PENELITIAN DAN \\ PEMBAHASAN}

\subsection{Hasil Penelitian}

\section{A. Uji Instrumen Penelitian \\ 1. Hasil Uji Validitas}

Teknik korelasi yang digunakan dalam melakukan uji validitas adalah dengan metode Pearson's Product Moment yang menguji dua sisi yang terdapat pada program SPSS. Jika $r$ hitung lebih besar dari $r$ tabel dan nilai positif maka butir atau pernyataan atau indikator tersebut dinyatakan valid. Hasil uji validitas kuesioner dengan menggunakan program SPSS 24.0 adalah sebagai berikut:

Hasil Uji Validitas Variabel Lingkungan Kerja $\left(\mathrm{X}_{1}\right)$

\begin{tabular}{|c|c|c|c|c|}
\hline No. & Pernyataan & $\mathrm{r}_{\text {hitung }}$ & $\mathrm{r}_{\text {tabel }}$ & Keterangan \\
\hline 1 & $\mathrm{X}_{1.1}$ & 0.632 & 0,349 & Valid \\
\hline 2 & $\mathrm{X}_{1.2}$ & 0.790 & 0,349 & Valid \\
\hline 3 & $\mathrm{X}_{1.3}$ & 0.843 & 0,349 & Valid \\
\hline 4 & $\mathrm{X}_{1.4}$ & 0.888 & 0,349 & Valid \\
\hline 5 & $\mathrm{X}_{1.5}$ & 0.632 & 0,349 & Valid \\
\hline 6 & $\mathrm{X}_{1.6}$ & 0.790 & 0,349 & Valid \\
\hline 7 & $\mathrm{X}_{1.7}$ & 0.885 & 0,349 & Valid \\
\hline 8 & $\mathrm{X}_{1.8}$ & 0.649 & 0,349 & Valid \\
\hline 9 & $\mathrm{X}_{1.9}$ & 0.632 & 0,349 & Valid \\
\hline
\end{tabular}




\begin{tabular}{|c|c|c|c|c|}
\hline 10 & $\mathrm{X}_{1.10}$ & 0.790 & 0,349 & Valid \\
\hline 11 & $\mathrm{X}_{1.11}$ & 0.888 & 0,349 & Valid \\
\hline 12 & $\mathrm{X}_{1.12}$ & 0.885 & 0,349 & Valid \\
\hline
\end{tabular}

Hasil : Pengolahan data (2021)

Tabel 4.8

Hasil Uji Validitas Variabel Disiplin $\operatorname{Kerja}\left(\mathrm{X}_{2}\right)$

\begin{tabular}{|c|c|c|c|c|}
\hline No. & Pernyataan & $\mathrm{r}_{\text {hitung }}$ & $\mathrm{r}_{\text {tabel }}$ & Keterangan \\
\hline 1 & $\mathrm{X}_{2.1}$ & 0.442 & 0,349 & Valid \\
\hline 2 & $\mathrm{X}_{2.2}$ & 0.515 & 0,349 & Valid \\
\hline 3 & $\mathrm{X}_{2.3}$ & 0.811 & 0,349 & Valid \\
\hline 4 & $\mathrm{X}_{2.4}$ & 0.762 & 0,349 & Valid \\
\hline 5 & $\mathrm{X}_{12.5}$ & 0.554 & 0,349 & Valid \\
\hline 6 & $\mathrm{X}_{2.6}$ & 0.447 & 0,349 & Valid \\
\hline 7 & $\mathrm{X}_{2.7}$ & 0.811 & 0,349 & Valid \\
\hline 8 & $\mathrm{X}_{2.8}$ & 0.574 & 0,349 & Valid \\
\hline 9 & $\mathrm{X}_{2.9}$ & 0.811 & 0,349 & Valid \\
\hline 10 & $\mathrm{X}_{2.10}$ & .0769 & 0,349 & Valid \\
\hline
\end{tabular}

Hasil : Pengolahan data (2021)

Tabel 4.9

Hasil Uji Validitas Variabel Kinerja (Y)

\begin{tabular}{|l|c|c|c|c|}
\hline No. & Pernyataan & $\mathrm{r}_{\text {hitung }}$ & $\mathrm{r}_{\text {tabel }}$ & Keterangan \\
\hline 1 & $\mathrm{Y}_{1.1}$ & 0.630 & 0,349 & Valid \\
\hline 2 & $\mathrm{Y}_{1.2}$ & 0.718 & 0,349 & Valid \\
\hline 3 & $\mathrm{Y}_{1.3}$ & 0.756 & 0,349 & Valid \\
\hline 4 & $\mathrm{Y}_{1.4}$ & 0.756 & 0,349 & Valid \\
\hline 5 & $\mathrm{Y}_{1.5}$ & 0.625 & 0,349 & Valid \\
\hline 6 & $\mathrm{Y}_{1.6}$ & 0.854 & 0,349 & Valid \\
\hline 7 & $\mathrm{Y}_{1.7}$ & 0.795 & 0,349 & Valid \\
\hline 8 & $\mathrm{Y}_{1.8}$ & 0.436 & 0,349 & Valid \\
\hline 9 & $\mathrm{Y}_{1.9}$ & 0.818 & 0,349 & Valid \\
\hline 10 & $\mathrm{Y}_{1.10}$ & 0.622 & 0,349 & Valid \\
\hline 11 & $\mathrm{Y}_{1.11}$ & 0.854 & 0,349 & Valid \\
\hline 12 & $\mathrm{Y}_{1.12}$ & 0.795 & 0,349 & Valid \\
\hline
\end{tabular}

Hasil : Pengolahan data (2021)

\section{Hasil Uji Reliabilitas}

Uji reliabilitas merupakan uji yang digunakan untuk mengukur kuesioner yang merupakan indikator dari variabel atau konstruk. Suatu kuesioner dikatakan reliabel atau handal jika jawaban seseorang terhadap pernyataan adalah konsisten atau stabil dari waktu ke waktu (Ghozali, 2011). Reliabilitas instrumen penelitian diuji menggunakan rumus koefisien Cronbach's Alpha. Jika nilai koefisien alpha lebih besar dari 0,60 maka disimpulkan bahwa instrumen penelitian tersebut handal atau reliabel (Ghozali, 2011).

Berdasarkan hasil pengujian dengan menggunakan SPSS 24.0 didapatkan hasil uji reliabilitas dapat dilihat dalam tabel sebagai berikut : 
Tabel 4.10

Hasil Uji Reliabilitas Variabel Penelitian

\begin{tabular}{|l|c|c|}
\hline \multicolumn{1}{|c|}{ Variabel } & Cronbach's Alpha & N of Items \\
\hline Lingkungan Kerja & 0,954 & 12 \\
\hline Disiplin Kerja & 0,901 & 10 \\
\hline Kinerja & 0,938 & 12 \\
\hline
\end{tabular}

Hasil : Pengolahan data (2021)

\section{B. Uji Statistik Deskriptif}

Statistik deskriptif memberikan gambaran atau deskripsi suatu data yang dilihat dari nilai minimum, maksimum, rata-rata (mean), standar deviasi.Untuk memberikan gambaran analisis statistik deskriptif dalam

\section{a. Hasil Regresi Linear Berganda}

Pengujian hipotesis dalam penelitian ini dilakukan dengan menggunakan model analisis regresi linier berganda dan merupakan penelitian two-tail dengan tingkat signifikansi $(\alpha)$ 0,05. Perhitungan model regresi linier berganda dilakukan dengan bantuan SPSS 24.0.

Tabel 4.11

Hasil Uji Linear Berganda

\begin{tabular}{|c|c|c|c|c|c|c|}
\hline \multicolumn{7}{|c|}{ Coefficients $^{\mathrm{a}}$} \\
\hline \multirow{2}{*}{\multicolumn{2}{|c|}{ Model }} & \multicolumn{2}{|c|}{$\begin{array}{l}\text { Unstandardized } \\
\text { Coefficients }\end{array}$} & \multirow{2}{*}{$\begin{array}{c}\begin{array}{c}\text { Standardize } \\
\text { d }\end{array} \\
\text { Coefficients } \\
\text { Beta }\end{array}$} & \multirow[b]{2}{*}{$t$} & \multirow[b]{2}{*}{ Sig. } \\
\hline & & B & Std. Error & & & \\
\hline 1 & $\begin{array}{l}\text { (Constant } \\
\text { ) }\end{array}$ & -.048 & 3.083 & & -.015 & .988 \\
\hline & $\mathrm{X} 1$ & .582 & .118 & .574 & 4.944 & .000 \\
\hline & $\mathrm{X} 2$ & .523 & .151 & .403 & 3.471 & .002 \\
\hline
\end{tabular}

a. Dependent Variable: $Y$

Hasil : Pengolahan data (2021)

Pada penelitian ini menggunakan model persamaan yaitu sebagai berikut:

$$
\mathrm{Y}=-0,048+0,582 \mathrm{X}_{1}+0,523 \mathrm{X}_{2}+\varepsilon
$$

a. Nilai konstanta sebesar -,048 menunjukkan bahwa jika variabel lingkungan kerja dan disiplin kerja diasumsikan konstan atau sama dengan nol maka kinerja karyawan akan menurun sebesar - 0,048

b. Koefisien regresi variabel lingkungan kerja sebesar 0,582. Hasil ini menunjukkan bahwa semakin baik lingkungan kerja karyawan, maka kinerja maka akan meningkat sebesar 0,582

c. Nilai koefisien regresi variabel disiplin kerja sebesar 0,523. Hasil ini menunjukkan bahwa apabila semakin tinggi disiplin kerja yang dimiliki karyawan, maka kinerja karyawan akan meningkat sebesar 0,523 


\section{b. Hasil Koefesien Diterminasi}

Tabel 4.12

Koefesien Diterminasi

\begin{tabular}{|l|c|r|r|c|}
\hline \multicolumn{5}{|c|}{ Model Summary } \\
\hline Model & $\mathrm{R}$ & $\mathrm{R}$ Square & $\begin{array}{c}\text { Adjusted } \\
\text { R Square }\end{array}$ & $\begin{array}{c}\text { Std. Error of the } \\
\text { Estimate }\end{array}$ \\
\hline 1 & $.942^{\mathrm{a}}$ & .887 & .880 & 2.20669 \\
\hline a. Predictors: (Constant), X2, X1 \\
\hline
\end{tabular}

Hasil : Pengolahan data (2021)

Serta hasil perhitungan untuk nilai adjusted $\mathrm{R}^{2}$ dengan bantuan program SPSS, sebagai berikut :

a. $\mathrm{r}$ dalam analisis regresi berganda menunjukan korelasi (korelation pearson), yaitu korelasi antara dua variabel independent terhadap satu variabel dependent. Angka $r$ didapat 0.942, artinya korelasi antar variabel dengan lingkungan kerja dan disiplin sebesar 0,942. hal ini berarti terjadi hubungan yang kuat karena nilainya mendekati 1.

b. R Square (R) atau kuadrat dari R, yaitu menunjukan nilai koefesien determinasi. Angka ini akan diubah ke bentuk persen yang artinya persentase sumbangan pengaruh variabel independent terhadap variabel dependent. Nilai $\mathrm{R}^{2}$ sebesar 0,887 artinya persentase sumbangan lingkungan kerja, disiplin kerja terhadap kinerja sebesar 88,7\%, sedangkan sisanya $12,3 \%$ dipengaruhi oleh variabel lain yang tidak dimasukkan dalam penelitian ini.

\section{c. Uji Signigikansi}

\section{Uji ketepatan Model}

(Uji f)

Uji-f atau uji koefesien regresi secara bersama-sama digunakan untuk mengetahui apakah secara bersama-sama variabel independen berpengaruh signifikan terhadap variabel dependen. Dalam hal ini untuk mengetahui apakah variabel lingkungan kerja dan disiplin kerja berpengaruh secara signifikan atau tidak terhadap prestasi kerja. Pengujian menggunakan tingkat signifikansi 0,05

Tabel 4.13

Hasil Regresi

\begin{tabular}{|c|c|c|c|c|c|c|}
\hline \multicolumn{7}{|c|}{ ANOVA $^{a}$} \\
\hline \multicolumn{2}{|c|}{ Model } & $\begin{array}{l}\text { Sum of } \\
\text { Squares }\end{array}$ & df & $\begin{array}{l}\text { Mean } \\
\text { Square }\end{array}$ & $\mathrm{F}$ & \\
\hline \multirow[t]{3}{*}{1} & $\begin{array}{l}\text { Regressio } \\
n\end{array}$ & 1184.105 & 2 & 592.052 & 121.584 & $.000^{b}$ \\
\hline & Residual & 150.954 & 31 & 4.869 & & \\
\hline & Total & 1335.059 & 33 & & & \\
\hline \multicolumn{7}{|c|}{ a. Dependent Variable: Y } \\
\hline \multicolumn{7}{|c|}{ b. Predictors: (Constant), X2, X1 } \\
\hline
\end{tabular}

Hasil : Pengolahan data (2021) 
Berdasarkan hasil pengolahan data diperoleh nilai $f$ hitung $(121,584)$, sedangkan nilai $\mathrm{f}$ tabel $(3,305)$ dengan $p$-value $(0,000)<0,05$. Maka dapat berdasarkan hipotesis dapat disimpulkan

$\mathrm{H}_{0}: \mathrm{b}_{1}, \mathrm{~b}_{2} \neq 0$, artinya secara bersama-sama tidak terdapat pengaruh yang positif dan signifikan dari variabel bebas $\left(\mathrm{X}_{1}\right.$, $\mathrm{X}_{2}$ ) yaitu berupa lingkungan kerja dan disiplin kerja terhadap kinerja karyawan sebagai variabel terikat $(\mathrm{Y})$.

$\mathrm{H}_{1}: \mathrm{b}_{1}, \mathrm{~b}_{2}=0$, artinya secara bersama-sama terdapat pengaruh yang positif dan signifikan dari variabel bebas $\left(\mathrm{X}_{1}, \mathrm{X}_{2}\right)$ yaitu berupa lingkungan kerja dan disiplin kerja terhadap kinerja karyawan sebagai variabel terikat (Y).
Berdasarkan hasil dari output $\mathrm{F}$ hitung diperoleh sebesar 121,584. Untuk mencari $f$ tabel pada signifikansi 0,05 dengan derajat kebebasan $\mathrm{df}=\mathrm{n}-\mathrm{k}-1$ atau 34-2-1 = 31 maka diperoleh nilai untuk $\mathrm{F}$ tabel sebesar 3,305 Karena $f_{\text {hitung }}(121.584)$ $>\mathrm{f}_{\text {tabel }}(3,305)$, maka $\mathrm{H}_{\mathrm{o}}$ ditolak, $\mathrm{H}_{1}$, diterima artinya bahwa lingkungan kerja dan disiplin kerja secara bersama-sama (simultan) berpengaruh terhadap kinerja. .Selain itu dengan melihat nilai signifikan kurang dari 0,05, dapat disimpulkan bahwa model penelitian fit (goodness of fit).

\section{Uji ketepatan Model (Uji t)}

Uji t digunakan untuk mengetahui besarnya pengaruh masing-masing variabel independen secara individu. Hasil uji masing-masing hipotesis dapat dilihat pada tabel dibawah ini :

Tabel 4.11

Hasil Uji Linear Berganda

\begin{tabular}{|c|c|c|c|c|c|c|}
\hline \multicolumn{7}{|c|}{ Coefficients $^{\mathrm{a}}$} \\
\hline \multirow{2}{*}{\multicolumn{2}{|c|}{ Model }} & \multicolumn{2}{|c|}{$\begin{array}{l}\text { Unstandardized } \\
\text { Coefficients }\end{array}$} & $\begin{array}{l}\text { Standardize } \\
\mathrm{d} \\
\text { Coefficients }\end{array}$ & \multirow[b]{2}{*}{$t$} & \multirow[b]{2}{*}{ Sig. } \\
\hline & & $\mathrm{B}$ & Std. Error & Beta & & \\
\hline 1 & (Constant & .048 & 3.083 & & -.015 & .988 \\
\hline & $\mathrm{X} 1$ & .582 & .118 & .574 & 4.944 & .000 \\
\hline & $\mathrm{X} 2$ & .523 & .151 & .403 & 3.471 & .002 \\
\hline
\end{tabular}

a. Dependent Variable: $Y$

Hasil : Pengolahan data (2021)

Berdasarkan hasil pengujian uji t menunjukkan bahwa :

a. Pengujian variabel lingkungan kerja

Berdasarkan hasil dari output $t$ hitung diperoleh sebesar 4,944. Untuk mencari $t$ tabel pada signifikansi 0,05 dengan derajat kebebasan. $\mathrm{df}=\mathrm{n}-\mathrm{k}-1$ atau 34-2-1 = 31 maka diperoleh nilai untuk $\mathrm{t}$ tabel sebesar 2,040. Karena $\mathrm{t}$ hitung $(4,944>\mathrm{t}$ tabel $(2,040)$, artinya bahwa lingkungan kerja secara parsial berpengaruh terhadap kinerja.

b. Pengujian variabel disiplin kerja Berdasarkan hasil dari output $\mathrm{t}$ hitung diperoleh sebesar 3,471. Untuk mencari t tabel pada signifikansi 0,05 dengan derajat kebebasan. $\mathrm{df}=\mathrm{n}-\mathrm{k}-1$ atau 34-2-1 = 31 maka diperoleh nilai untuk $t_{\text {tabel }}$ sebesar 2,035. Karena $t$ hitung $(3,471)>\mathrm{t}_{\text {tabel }}(2,040)$, artinya 
bahwa disiplin kerja secara parsial berpengaruh terhadap kinerja.

\section{KESIMPULAN DAN SARAN- SARAN}

\subsection{Kesimpulan}

Pada bagian akhir dari penelitian ini, peneliti akan mengemukakan beberapa kesimpulan dan saran yang didasarkan pada temuan hasil penelitian dan uraian pada bab-bab sebelumnya mengenai masalah yang diteliti

1. Berdasarkan hasil uji t dimana variabel lingkungan kerja berpengaruh signifikan terhadap kinerja karyawan, dimana nilai $\mathrm{t}_{\text {hitung }}(4,944)>$ dari nilai $\mathrm{t}$ tabel $(2,040) \quad$ sehingga variabel lingkungan kerja berpengaruh terhadap kinerja karyawan.

2. Berdasarkan hasil uji $\mathrm{T}$ dimana variabel disiplin kerja berpengaruh signifikan terhadap kinerja karyawan, dimana nilai $\mathrm{t}_{\text {hitung }}(3,471)>$ dari nilai $\mathrm{t}$ tabel $(2,040)$ sehingga variabel disiplin kerja berpengaruh terhadap kinerja karyawan.

3. Berdasarkan hasil uji $F$ dimana variabel lingkungan kerja dan disiplin kerja berpengaruh secara simultan terhadap kinerja karyawan, dimana nilai $\mathrm{f}$ hitung $(121,584)>$ dari nilai $f$ tabel $(3,305)$ sehingga variabel lingkungan kerja dan disiplin kerja berpengaruh secara simultan terhadap kinerja karyawan.

\subsection{Saran-saran}

1. Untuk meningkatkan dan menggairahkan karyawan dalam bekerja hendaknya pihak manajemen memperhatikan lingkungan kerja yang nyaman, dimana lingkungan fisik harus tertata dengan baik agar karyawan dalam bekerja tidak merasa jenuh dan membosankan.

2 Untuk meningkatkan kedisiplinan yang baik agar karyawan bersedia untuk mengubah suatu perilaku serta sebagai suatu upaya untuk meningkatkan kesadaran dan kesediaannya mentaati semua peraturan perusahan dan norma- norma sosial yang berlaku, hendaknya perusahaan/manajemen memberikan suatu motivasi terhadap karyawan untuk dapat merangsang lebih giat lagi bekerja.

3. Guna meningkatkan kinerja karyawan hendaknya perusahaan /manajemen lebih sering mengadakan pengawasan, guna meningkatkan kedisiplinan terhadap karyawan untuk bekerja lebih baik lagi guna menghasilkan pekerjaan yang memuaskan sesuai dengan target perusahaa

\section{DAFTAR PUSTAKA}

A.A. Anwar Prabu Mangkunegara. Evaluasi Kinerja SDM, Cetakan 2 Refika Aditama, Bandung, 2015

Alex S. Nitisemito, Manajemen Personalia, Manajemen Sumber Daya Manusia, Ghalia, Jakarta, 2015

Ahmad Tohardi, Pemahaman Praktis Manajemen Sumber Daya Manusia, Universitas Tanjung Pura, Mandar Maju, Bandung, 2015

Aplia Ferawati, Pengarh lingkungan kerja dan disiplin kerja terhadap kinerja karyawan PT. Cahaya Indo Persada Surabaya, Jurnal AGORA Vol. 5, No.1, 2017

Budi W Soetjipto, Paradigma Baru Manajemen Sumber Daya Manusia, Amara Books; Yogyakarta, 2015

Etty Siswati, Pengaruh Lingkungan Kerja Dan Disiplin Kerja Terhadap Kinerja Karyawan Pada Pt.Perkebunan Nusantara Vi Unit Usaha Bukit Cermin Kabupaten Sarolangun, Jurnal Eksis Volume 7 No. 2, November 2016

Edy Sutrisno, Manajemen Sumber Daya Manusia. Pertama. Penerbit Kencana, Jakarta, 2016

Fred Luthans, Perilaku Organisasi, Diterjemahkan oleh Vivin 
Andika, Yuwono, Edisi ke Lima, Andi, Yogyakarta, 2015

Imam Ghozali, Aplikasi Analisis Multivariate dengan Program SPSS. Edisi Ketujuh. Semarang : Badan Penerbit Universitas Diponegoro, 2015

Hani Handoko, Manajemen Personalia \& Sumberdaya Manusia (Edisi 2), BPFE. Yogyakarta, 2015

Husein Umar, Riset Sumber Daya Manusia Dalam Organisasi, Gramedia Pustaka, Jakarta, 2015

Komarudin, Manajemen, Edisi IX, Jakarta : Bumi Aksara. 2015

Logahan, Pengaruh LingkunganKerja dan Stres Pekerjaan Terhadap Kinerja Pekerja di PT Nemanac Rendem. Tarakanita (skripsi tidak dipublikasi), 2015

M. Singarimbun, Metode Penelitian Survey, Pustaka LP3S, Jakarta, 2016

Malayu S.P Hasibuan, Manajemen Sumber Daya Manusia , Bumi Aksara, Jakarta, 2015

Marihot Tua Efendi Hariandja, Manajemen Sumber Daya Manusia, Grasindo, Jakarta, 2015

Robert L. Mathis, Manajemen Sumber Daya Manusia, Edisi 13, Salemba Empat, Jakarta, 2015

R. Heidjdrahman dan Suad Husnan, Manajemen Personalia, Cetakan Kedelapan, Djambaran, Jakarta, 2015

Sedarmayanti, Sumber Daya Manusia Dan Produktivitas Kerja, Edisi Revisi, Mandar Maju, Bandung, 2015

Susilaningsih, pengaruh kepemimpinan, disiplin, motivasi, pengawasan, dan lingkungan kerja terhadap kinerja" Excellent Vol. 1 No.2. September 2010

Sugiyono, Metode Penelitian Bisnis, Alfabeta, Bandung, 2015

Veithzal Rivai, Manajemen Sumber Daya Manusia Untuk Perusahaan, Grafindo, Jakarta, 2015

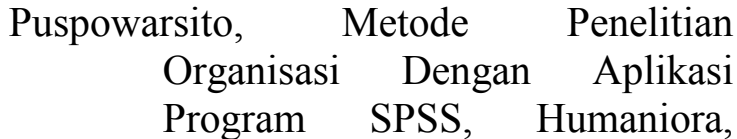
Bandung, 2011 